\title{
Problematic of Identity: A Close Study of Taslima Nasrin's Lajja
}

\author{
Navya Chandran \\ Department of English (Mphil Student) \\ Sree Sankaracharya University of Sanskrit, Kalady \\ navyachandran1992@gmail.com
}

\begin{abstract}
Taslima Nasrin is hailed as one of the most powerful voices in the literary canon of Bangladeshi English Literature and her epoch making work Lajja is rightly regarded as a perfect example of 'gendered subaltern narrative'. In the novel, she presents a cross - section of Bangladeshi society after twenty years of its separation from Indian sub - continent, caught up in the trauma of post colonial nation building and identity consciousness. The complex sense of Bangladeshi nationalism, which is inextricably linked to its religious identity, is the pivot on which Lajja turns. The immediate backdrop of the novel is the demolition of Babri Masjid, the sixteenth century religious edifice situated in India that inflicted a series of barbaric tyranny in Bangladesh against the minority Hindus who were soon labelled as the "Other".

The focus of Nasrin's novel is limited to Dutta family, a metaphor for the minority Hindu population in Bangladesh, who were forcefully classified as the enemy and outsider clan during the time of crisis. Sukumar Dutta, the head of the family, who identifies himself as an atheist, communist, male Bangladeshi is forcefully classified as a Hindu under binary logic. There is a politicisation of his identity when there is a dissonance between how an individual want to define him and where social agents wants to place him. Identity thus cease to be what an individual considers to be his sense of self and proves to be that character or personality of an individual as recognised by society.
\end{abstract}

Keywords: Religious fundamentalism, Imagined communities, identity Politics, ethnicity Crisis, egocentrism.

\section{INTRODUCTION}

Lajja is the magnum opus of Taslima Nasrin in which she adresses a large spectrum of threats faced by Bangladeshi nationalism today. The bond formed between national identity and religious identity has led to the formulation of the postulate that anyone who is not a Muslim is an enemy, outsider and non- Bangladeshi. This has led to the rapid exclusion of the minority Hindu population from the cultural scene, striking them off from enjoying any privilege as a Bangladeshi citizen. The shock of being excluded from an ethnical group on the basis of religion is devastating for the Hindu population as portrayed by the Dutta family in Lajja.

\section{Problematic of Identity: A Close Study of Taslima Nasrin's LajJa}

Bangladeshi English literature, as the name suggests, refers to the body of literary works written in the English language in Bangladesh and by Bangladeshi diaspora, the legacy of which can be traced to pre-independent undivided Bengal. The litearary canon of Bangladesh contains works of prominent writers like Michael Madhusudan Dutt, Rabindranath Tagore, Sean Dean Mahomed, Begam Rokeya, Tahmima Anam, Monica Ali, Taslima Nasrin and so on. These writers use English as a medium to connect to the larger corpus of world literature, a rejection of the insularity of contemporary Bangla language literature, which is an expansive, if closed, system. Any study on Bangladeshi literature would be incomplete without a mention about the epoch making writer and Islamic feminist Taslima Nasrin. She takes up the cause of thousands of Muslim women in Bangladesh, mistreated in the hands of violent religious fanatics. Lajja is her magnum opus, where she represents a cross - section of Bangladeshi society after twenty years of its seperation from Indian sub - continent.

The primary focus of the novel is the family of Duttas with four central characters - Sukumar Dutta, Kiranmoyee, Suranjan and Maya, who falls prey to the Islamic fundamentalists in Bangladesh for having been born into the minority community of Hindus. The immediate backdrop of the novel is the demolition of the sixteenth century edifice Babri Masjid, which led to devastating fallout in Bangladesh where temples were destroyed and the Hindu minority community became victims of 


\section{Navya Chandran}

insensate and barbaric violence at the hands of religious fanatics. Women were raped, men were beaten up, their property destroyed and looted and their lives were made miserable by random terror and orchestrated tyranny.

Nasrin dedicated the book 'to the people in Indian Sub-continent' beginning the text with the words 'let another name of religion be humanism'. The central theme of Lajja is explained by Nasrin by the following words - "Ironically all religions points towards one goal - peace. Yet it is in the name of religion that so much blood is shed and so many people have suffered. It is indeed a pity that even in the close of twentieth century, we have had to witness such atrocities, all in the name of religion" (Lajja, 35) The novel follows thirteen fearful days in the life of a Hindu family immediately after demolition. Meaningfully, the thirteen day which signified the end of funeral rituals for Hindus is the day when Duttas wrenches themselves away from their beloved country to take shelter in India.

Lajja adorns a unique position in the history of the Bangladeshi literature for exposing the age old strife between various fractions of Indian sub-continent and voicing protest against the religious fundamentalists for their brute and inhumanly behaviour against minority Hindus. The aggressive reassertion of Muslim identity had an adverse effect on the average Hindu Psyche. Not only communal Hindus, but also secular Hindus were baffled. As identity consciousness in the majority community increased, there was a forceful classification of non - Muslims as Hindus under binary logic. This dangerous situation strained the pluralistic fabric of Bangladeshi society. Their identity was questioned - the central and only factor that defined them was their religious identity. Their sense of oneness as a nation was cut off for the very fact that Bangladesh was once and for all a land for Muslims. Duttas decides to leave the land with a huge sense of loss and with a big burden of identity and ethnicity crisis.

\section{Problematic of Identity and Ethnicity}

The concept of identity is main fold, hard to define and evades many ordinary methods of measurement. The twentieth century leading scholar of Identity, Erik Erikson, termed the concept of "all - pervasive" but also "vague" and "unfathomable" identity. The infuriating inescapability of identity is well demonstrated in the work of the distinguished social theorist Leon Wieseltier. In 1996, he published the book, Against Identity, denouncing and ridiculing the fascination of individuals with that concept. In the book Who are we? written by Samuel P. Huntington, identity is defined as an individual's or group's sense of self. It is a product of self-consciousness that I or We possess distinct qualities as an entity that differentiates me from you and us from them. Identity is thus the images of individuality and distinctiveness held and projected by a person and formed through relations with significant 'others'.

Identities are important because they shape the behaviour of people. Both individual and group have identities. Individuals, however, modify their identities in groups. As social identity theory has shown, the need for identity leads them even to seek identity in an arbitrarily and randomly constructed group. An individual may be a member of many groups and hence is able to shift identities. These multiple identities may be ascriptive, territorial, economic, cultural, political, social and national. Identities are, overwhelmingly constructed. People make their identity, under varying degrees of pressure, inducements and freedom. In an often - quoted phrase, Benedict Anderson described nations as "imagined communities" (38). Identities are imagined selves; they are what we think we are and what we want to be. Apart from ancestry, gender (and people occasionally change that) and age, people are relatively free to define their identity as they wish, although they may not be able to implement those identities in practice. They may inherit their ethnicity and race but these can be redefined or rejected, and the meaning and applicability of the term "Identity Politics" comes into play.

The term identity politics has been used in political and academic discourses since the 1970s. Identity becomes problematic when people are unable to achieve an identity because they are not welcomed by those who already have that identity. The crucial post - Cold War issue for East European peoples was whether the West would accept their identification of themselves as a part of the West. Westerners have accepted Poles, Czechs and Hungarians. They are less likely to do that with some other Eastern European peoples who also want a Western identity. They have been quite reluctant to do so with the Turks, whose bureaucratic elites desperately want Turkey to be Western. 
In Lajja, Sudhamoy identifies himself as an atheist, communist, male and Bangladeshi. He is not a practising Hindu. But according to the binary logic if he is not a Muslim he is categorised as a Hindu forcefully. There is no end to the compromises demanded from Dr Dutta. He has to sell his ancestral property for a pittance, he has to forgo promotions that he is eligible for, he has to give up wearing dhoti and pajamas and his wife has to delete overt aspects of her Hindu married identity. She stops applying vermillion on her hand and gives up wearing the white conch shell bangles. However Sudhamoy has a positive outlook towards the hostile atmosphere of his country.

Suranjan finds his identity in flux. His attempt to define his identity doesn't take a perfect shape. He is insensitive to the plight of his family and their fears. He couldn't find a reason why he should fear his friends and others just because they belong to a different religious community. Suranjan in a rebellious mood argues "Why should he flee his home simply because his name was Suranjan Dutta? Was it necessary for his family - Sudhamoy, his father, Kiranmoyee, his mother and Nilanjana, his sister - to run away like fugitives just because of their names? Would they have to take refuge in the homes of Kamal, Belal or Haider just as they had done two years back" (Lajja, 1).

Suranjan is an atheist. He has no emotional contacts with any temple or the idols installed in them, but the systematic and selective destruction of Hindu places of worship and the killing of Hindus forces him to re-interpret reality. He finds it flabbergasting when he is held responsible for the demolition of a mosque in another country he has never visited. His bitterness increases as he witnesses the unmistakable polarization of the country into the binaries of us and them. Finally, he understands that the cost of staying on in his home country is too much to bear. He has to become not only a Hindu but a militant one to confront the militants of the other side. Suranjan's predicament is not different from that of any other intelligent and progressive youngster anywhere. What hurts him most is not the religious persecution but the forced identity thrust upon him by an unrelenting system and his total inability to offer resistance. He prefers to migrate to a liberal and tolerant India which does not force him to practise the religion he is born into. The binary logic of his home country has no such offers to make.

Nasrin narrates an incident to show how Suranjan gets to understand his forced identity as a Hindu. As a child, he had known that he was a Hindu, but hadn't quite known what it meant. While Suranjan was at his lower primary class, he had a massive arguement with a Muslim boy named Khaled. When this arguement reached its peak, the boys had abused each other with the worst obscenities they could sum up. It was then the Muslim boy angrily referred to him as a Hindu. Suranjan was sure that the word Hindu was derogatory as swine or dog. It was only after he had grown up somewhat that he learnt that Hindu was a noun describing the religious community to which he belonged. When he was old enough to make up his mind on the matter he declared that he was above all, first, a human being and then Bengali by race. No religion had created this race and he wanted his people to know no communal barriers and live together in perfect harmony.

Nasrin hereby argues that fascinating process of negotiation is observed whenever there is a dissonance between how an individual want to define him and where social agents wants to place him. Thus Sudhamoy has an identity as a Hindu forced upon him. The twin processes of abstraction and generalisation used simultaneously lead to a high degree of comfort with stereotypes. These negotiations actually act as agents of change as they introduce new elements in social discourse and contribute towards the shaping of social debates. It is interesting to note how the two processes of behavioural confirmation and self verification help in constructing identities. Behavioural confirmation takes place when the identity provider successfully makes the identity receiver behave in accordance to the expectancies of the former. Self verification is the reversal of this process. In this, the identity receiver is able to behave in accordance with the receivers self-views or identities. Both the processes help in reinforcing the stereotypes.

Identity is thus the defining character or personality of an individual as recognised by society. To define themselves, people need an Other. This helps the individual groups to believe that their group is better than the other groups. Their sense of self rises and falls with the fortunes of the groups with which they identify and with the extent to which other people are excluded from their group. Ethnocentrism, as Mercer puts it, is "the logical corollary of egocentrism". Even when their group is totally arbitrary, temporary and minimal, people still, as social identity theory predicts, discriminate in favour of their group as compared to other group. 
Recognition of differences does not necessarily generate competition, much less hate. Yet even people who have less psychological need to hate can become involved in processes leading to the creation of enemies. Identity requires differentiation. Differentiation necessitates comparison, the identification of ways in which "our" group differs from "their" group. Comparison, in turn generates evaluation. Group egotism leads to justification. "our" ways are better than "their" ways. Since the members of other groups are engaged in similar processes, conflicting justification leads to competition. Members of different groups will engage in different activities to demonstrate their superiority over the other group. Competition leads to antagonism and the broadening of what may have started as the perception of narrow differences into more intense and fundamental ones. Stereotypes are created, the opponent is demonised, and the other is transmogrified into the "enemy".

The identity of family of Duttas as Hindus is highlighted by the Bangladesh society. Narrower and broader identities in a single hierarchy may either reinforce or conflict with each other. In a famous phrase, Edmund Burke argued that "To be attached to the subdivision, to love the little platoon we belong to in the society, is the first principle of public affections. The love to the whole is not extinguished by this subordinate partiality". But as we see in Lajja, religious identity becomes the sole, distinguishing people into various social groups and the identity over powers all other identities including the national identity, which leads to the downfall of Dutta family. Despite the acceptance of plurality, people try to search for commonality in a manner that it distinguishes them from various others and also co-relates the ones who are 'similarly distinguished'. Thus these identities celebrate distinction as well as homogeneity. Identity construction, therefore, uses the twin principle of exclusion as well as inclusion. Last century has witnessed intensified efforts at consolidation of both individual as well as categorical identities. Taslima Nasrin's life and writings reflect this trend conclusively.

\section{THE GENDER DIVIDE}

Subordination of women is a visible feature of most stages of recorded history, and is prevalent in large parts of the world. The extent and form of that subordination has been conditioned by the social, economic and cultural environment in which women have been placed. Through her book, Taslima Nasrin beautifully portrays the double disability imposed on women of minority communities. She has sharply exposed the differential impact of social exigencies on men and women. Minu Mehta, in her study Looking through Identity Lens: A Cross Cultural Perspective with Special Reference to Taslima Nasrin's Lajja remarks: "The gender identity is so powerful and overriding that it canopies and hides everything else" (Mehta 1).

Kiranmoyee, wife of Sukumar Dutta, suffers as much as any other women during the freedom struggle of Bangladesh. In addition, she has to endure the ignominy of deleting her Hindu identity as the family goes on exile to escape from Pakistani persecutors. Maya, Sudhamoy's daughter, however pays the highest price of being a minority woman. Her double abduction, as a child and as a young woman of twenty one is testimony to this fact. Nasrin's device of Maya's ambiguous fate makes her vulnerability all the more fragile. She suffers more than the Muslim prostitute her brother rapes. That women suffer in times of crisis is a foregone conclusion.

In Bangladesh, as in any other Muslim majority society, Islamist forces have emphasized on the importance of women adopting traditional practises, such as wearing the veil, as a cultural symbol and a weapon in the movement of Islamization against western modernisation. Modernisation is imagined as 'immoral' and 'dangerous'. Some activists have also tried to reinvent the religion by adding some elements of modernity into Islamic tradition. In reaction to the image of commoditisation of women's body in western modernity, the construct women wearing hijab in the public spaces as an image of 'modern Muslim women'.

Kiranmoyee, the wife of Sudhamoy Dutta, is a quintessential, sacrificing wife-mother who has never learnt to assert herself. Her primary concern is the well being of her family and she is willing to sacrifice anything to keep her family together. She keenly observes everyone at home but she has no voice to raise an argument. She is willing to accept her son's girl friend though she is a Muslim. She also happily cooks meat in her house when she is asked to do it by her husband. During the time of violence, Kiranmoyee is forced to take up Muslim pseudo names. Kiranmoyee had stopped using sindur in the parting of her hair and loha and sankha on her wrists as was expected of every married Hindu women. But she found it quite difficult to give up her bridal bangles and vermillion. 
Maya shows the impact of gender disability in a more pronounced way. She pays the highest price for being a minority woman. Her double abduction, as a child and as a young woman of twenty one adds to this fact. Where the case of kidnapping was concerned, there dint appear to be any distinction in the choice of victims, for both Hindu and Muslim women were kidnapped. The emotional trauma that victims like Maya felt were same as that of the pathetic plight of their families, like that of the Duttas, no matter what their religion was.

If one closely observes the women in Bangladesh as portrayed in the novel, they have become complicit in a system which subordinates them. Their life is located at the intersection of class, religion and patriarchy. These structures can all work to oppress them, as in the case of Hindu minority women in Bangladesh. But women belonging to Muslim majority enjoy few privileges and also wield a degree of power. These benefits are available to them only if they conform to the patriarchal codes of their family and communities.

Compliance brings them gains, both material and symbolic. Deviance, on the other hand, expels them from material resources of their family, of which they can partake only on condition of 'good' behaviour. The compliance of women or the consent they extend to structures that are oppressive is however 'invisibilised' under the seemingly more neutral notion of upholding 'tradition' or the specific 'cultures' of families or of communities, then moving outward to a nation whose cultural repository somehow resides specifically on women.

\section{Conclusions}

The merit of Lajja lies in its sublime power to disturb even its best reader. Lajja is richly ornamented with activities that took place during the riots and is certainly a good source for those who want to know how the Babri Masjid demolition changed the lives of millions of Hindus and Muslims residing in the Indian sub-continent. Bangladesh has a secular democracy, but the state religion is Islam. "It has been very rare for a person from a majority community to write about the treatment of a minority" says Zaman Habiba, a London based critic and lecturer on post-colonial literature.

Nasrin identifies the root cause of violence in Bangladesh as religious fundamentalism. Religious fundamentalists use religion, along with culture, caste, ethnicity and nationalism to further their political goals. It includes spread of an ideology of hatred and intolerance towards those from other religions or who do not agree with their specific religious interpretations. They also employ coercive methods to control people and they use direct violence to silence opponents from outside as well as within the community.

Through Lajja, Taslima Nasrin was ranged against a host of enemies; Islamic tribalism, fossils of patriarchy, the privileged establishment, the traitorous razakars, the illiterate maulvis and cynical elite. She, perhaps unwittingly, took on all these monsters singlehandedly. She bore a hole in their medieval egos and pathological ignorance, as she tore to shreds their age old immoralities and traditional hypocrisies.

Presenting the minority population as a "threat" or "excess", the religious fundamentalists acquire the consent of the majority masses. In their autocratic, patriarchal ideology and methods, they pose a threat to democracy and to women's rights. Women are central to religious fundamentalist strategies, as they play a dual role both as reproducers of the community and as symbols of family, community and religious "honour". Religious fundamentalists seek to control the mobility and sexuality of women of other group as one of the most effective strategies of dishonouring that community as a whole.

The identity of an individual is shaped by his/her self perceptions of the world surrounding him/her based on religion, race, class, economic and social status. As in Lajja, a crisis situation like demolition of the religious centre Babri Masjid arouses a situation of defining people on the basis of their religious identity alone. There is a binary logic that anyone who is not a Muslim is an enemy. A Bangladeshi began to be solely described in terms of his religious identity. His past is erased, his history turned out to be insignificant.

There arouse a dichotomy between where an individual wants to place himself and where the society places him forcefully. So the identity politics emerges. Sudhamoy and Suranjan consider their primary identities as Bangladeshi citizens. But their only identity that acquires meaning during the time of the crisis is their religious identity. They become second class citizens in a country that they thought was their homeland. 


\section{Navya Chandran}

Nasrin detests fundamentalism because it does not believe in individualism, liberty or personal choice, or plurality of thought. She says that fundamentalists believe in a particular way of life, they want everybody in their particular straitjacket, and dictate what an individual should eat, what he should wear, how he should live everyday life. She protests against the fundamentalist authority which deprives mankind of individual liberty. She does not accept fundamentalism as an alternative to secular ideas.

Identity construction uses the twin principles of exclusion as well as inclusion thus differentiating between individual and categorical identities. Taslima Nasrin's life and writings relict this trend of identity conclusively. The success of the novel Lajja lies in Nasrin's ability to capture the trauma of the minority community, despite belonging to the majority community. Lajja literally means shame and true to this title, every human being, after reading the book, would be ashamed of the religious fanaticism that exist today in various forms in various parts of the world.

When it comes to atrocities against women, gender disability becomes a more grave issue than identity. Nasrin interprets the plight of women as a consequence of narrowing of social spaces. She has sharply exposed the differential impact of social exigencies on men and women. Almost no experience is gender neutral and for women, gender identity is so powerful and overarching that it canopies everything else. Women are in the process of describing their identity, if only they had one. Any period of crisis saw the exploitation of women just like what happened in Bangladesh. When it came to women, religion did not actually matter. As women, they were exploited and subordinated. No one raised slogans for them; no one cared for their well being. Taslima Nasrin stands as a symbol of resistance against Islamic fanatics and male oppression. She is rightly called 'female Rushdie'. Taslima out and out rejects all the religions including Islam for suppressing the fundamental rights of women.

Nasrin uses the techniques of naturalisation in her work. She adopts a direct way of writing as she did not take up esoteric or complicated theoretical issues in her novel. Her language and dialogues centre on the shackles and restrictions that blind mankind in a conservative, religion based society. Her prose style is sharp, incisive, colloquial, marinated in intense passion. Through her writings she fights for the modernisation of the state and society. Through this novel, Nasrin takes the license to explore the emotional and personal impact of contending political forces in Bangladesh. She tried to condemn the fundamentalist allegiances that divide friends and lovers according to religion.

The only regret is that several other Taslimas in making, conscientious and capable, perhaps remained suppressed because of the intimidating examples of her travails as a women, as a writer, as a dissident, as an independent thinker. Taslima opened the doors and windows for others to breathe the fresh air of freedom of thought and expression and venture forth, to stamp out the fog of obscurantism and to get rid of the choking miasma of inhuman and enslaving superstitions.

The merit of Lajja is not in its literary quality or the solution opted for the protagonists. Obviously migration is not a practical solution to the problem of relentless religious persecution. Neither is the book the best literary work on the subject. However the book is important on the account of the clarity and sincerity with which it raises the question of identity construction and identity politics. The unending lists and names of minority temples and individuals vandalised, killed and dishonoured shows the huge strength of the identity constructers.

Identities sustain themselves by feeding on the inertia. Therefore once constructed, they offer stiff resistance to any attempt of change. Science, rationality, and utopian intellectual constructs often form basis of forging new identities. To what extent these new constructs sustain themselves depends on how successful they are holding to the emotional appeal of people. Attempts of enforced identities are also seen in Russia, Iran and Turkey. The ascendance radical fundamentalism and complete intolerance of dissent indicates that the architects of this form of identity construct have succeeded in capturing public attention, even in the present era. The length of their life span is inversely dependent of the strength of voices of dissent like Taslima Nasrin.

Talking about ethnicity, due to unabated persecution, intimidation and forceful conversion to Islam, the Hindu minority population in Bangladesh kept on dwindling steadily and now stands at the meagre ten percentage of the total population in Bangladesh. Ethnic cleansing of minorities in Bangladesh (then East Pakistan) started in 1947. Over half-a-century has passed with no end is in sight. Minorities in Bangladesh, including women and children were subjected to extreme brutality 
and torture following the last National Election in Bangladesh held in October 2001, forcing many families to migrate out of their "Homeland of generations" for physical safety.

In the recent past, there have been several cases of brutal killings of prominent members of minority communities in the strategic Chittagong and its Hill Tracts, by armed gang of Islamic fanatics. Pascal is right when he says that "Men never do evil so completely and cheerfully as when they do it from religious conviction." But the ultimate message spread by all religion is that of love and harmony. Taslima Nasrin's book intends to erase the element of fundamentalism and communalism from contemporary society. Hence the relevance ant universal appeal of Lajja.

\section{REFERENCES}

[1] Asghar Aliengineer, Lifting the veil, Bombay: Sangam Books Ltd, 1995, ch. 1, pp. $24-27$.

[2] Samuel Huntington, Who Are We, UK: Simon \& Schuster UK Ltd, 2004, ch 5, pp. 87 - 94.

[3] Ronald Johnstone, Religion in society, U.S.A.: Pearson Education Inc, 2007, ch 2, pp. 13 - 42.

[4] Minu Mehta, Looking through the Identity Lens: A cross Cultural Perspective with Special Reference to Taslima Nasrin's Lajja, 13 Feb 2014, Web.

[5] Taslima Nasrin, No Country for Women, New Delhi: Vitasta Publishers, 2003, ch 7, pp. 48 - 49.

[6] Habiba Zaman, Violence against women in Bangladesh: Issues and Responses, 11 October 1999, Web.

\section{AUTHOR's BIOGRAPHY}

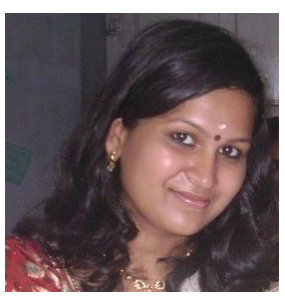

Navya Chandran, is a research scholar from Kalady Sri Sankara University of Sanskirt. She has worked briefly as reporter for Indian Express, kochi. Currently pursuing her research in Dalit and Canadian studies. 